\title{
Электронные
} документы

Доступность информации

и библиотеки

в местах лишения свободы в России: проблемы

\section{доступности инсрормации}

В настоящее вреля количество лии, содержащихся в условиях изоляиии от общества, достаточно велико. Лица, отбывающие наказание в виде реального лишения свободы по приговору суда, должны илеть доступ киенностял, сосредоточенныл в библиотеках, а также с полощью Интернета получать необходилую для салообразования инфорлацию.

Ключевые слова: библиотека, Интернет, леста лишения свободь, арестант, заключенныци, колония.

И стория развития российской культуры несомненно связана с литературой, издательской деятельностью и просветительством.

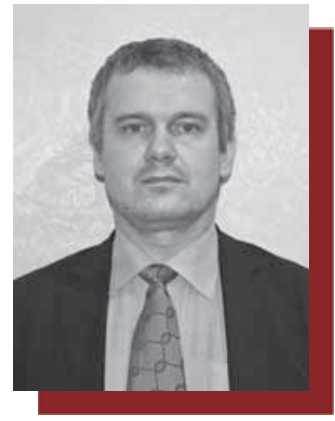

Сергей Владимирович

Шошин,

доцент кафедры уголовного, уголовно-исполнительного права и крилинологии

Саратовского государственного университета им. Н.Г. Чернышевского, кандидат юридических наук
Важную роль сыграли в этом и библиотеки. Часть населения России имела печальный опыт близкого личного знакомства (иногда на протяжении достаточно длительного периода) с фондами библиотек в местах лишения свободы. Не имеет значения социальный статус подобных пользователей таких библиотек - были ли это заключенные или сотрудники администрации мест лишения свободы, в любом случае анализируемый период времени относится к культурному пласту не только прошлого (далекого и не очень), но и современности [7].

В современных российских условиях количество лиц, содержащихся в условиях изоляции от общества, составляет около 1 млн человек [8]. Следует полностью согласиться с мнением А.Е. Шапошникова о том, что чтение и библиотека в глазах арестанта - осколок прежней, свободной жизни, источник интересной информации, благодатное отвлечение от тяжелой действительности, средство творческой самореализации. По 
данным отдельных исследований, не менее 80\% арестантов пользуются библиотекой в следственном изоляторе [5] и $25-28 \%$ - к колонии [1], что открывает определенные возможности социализирующего и воспитательного воздействия [6].

Лица, отбывающие наказание в виде реального лишения свободы по приговору суда, должны иметь доступ к ценностям, сосредоточенным в библиотеках России. Изложенное положение в полной мере соответствует содержанию правила 40 из «Минимальных стандартных правил обращения с заключенными» от 30 августа 1955 г., которые были приняты на первом Конгрессе Организации Объединенных Наций по предупреждению преступности и обращению с правонарушителями, состоявшемся в Жееневе, и одобрены Экономическим и социальным Советом в его резолюциях 663 C (XXIX) от 31 июля 1957 г., 2076 (LXII) от 13 мая 1977 г. и 1984/47 от 25 мая 1984 года. Указанное правило гласит: «В каждом учреждении должна быть библиотека для пользования всеми заключенными, должным образом оборудованная и оснащенная художественной и учебной литературой, заключенных необходимо поощрять пользоваться всеми библиотечными услугами» [4, с. 7].

Такие граждане после своего освобождения, как предполагается, должны будут активно включиться в процесс жизни, для чего им необходимо обладать неким объемом информации, потребность в которой может возникнуть на свободе.

Сегодня с использованием Интернета стало реальностью обучение иностранным языкам в режиме реального времени. При этом больших материальных затрат для реализации подобного процесса получения информации, как правило, не требуется. Кроме того, в Интернете имеются технически совершенные программные продукты, предназначенные для перевода текстов на различных языках. К числу очевидных достоинств таких инновационных технологий можно отнести бесплатность многих из них. Например, весьма перспективен в этом отношении переводчик, размещенный на сайте www.google.com. Texнология, разработанная специалистами указанной компании и предоставленная в безвозмездное пользование посетителям всемирной сети, позволяет производить поиск интересующей информации на сайтах различных народов мира. Также указанная технология практически мгновенно позволяет переводить на различные языки целые сайты. Скорость подобной деятельности практически полностью зависит от качества и степени быстродействия компьютерной техники, используемой конкретным конечным потребителем информации.

C помощью Интернета люди, пользующиеся услугами библиотек, расположенных на территории мест лишения свободы, могли бы с успехом не только для себя, но и с пользой для остальных членов российского общества получать информацию, повышать самообразование. В качестве примера можно привести США, где заключенные свободно, но при надлежащем надзоре за ними со стороны персонала мест лишения свободы, активно и результативно пользуются возможностями глобальной сети.

Вопрос о целесообразности использования в библиотеках для заключенных возможностей Интернета рассматривается в «Руководстве по библиотечному обслуживанию заключенных», предназначенном для библиотекарей, администрации библиотек, руководства колоний, законодательной и исполнительной ветвей власти и других структур, ответственных за управление и финансирование библиотек в местах отбывания наказания [4, с. 5]. Пункт 5.5 данного Руководства устанавливает, что в образовательных и исправительно-воспитательных целях заключенные должны иметь контролируемый выход в Интернет, если это не противоречит условиям безопасности в тюрьме.

Очевидным является и предоставление в рамках библиотечного обслуживания заключенных возможности поиска в Интернете места 
возможного трудоустройства после освобождения. С помощью ресурсов Интернета заключенные могут, при соответствующих условиях, поддерживать связь с членами своих семей и другими людыми, а также устанавливать новые контакты, которые могут помочь в решении бытовых вопросов, возникающих после освобождения осужденного из мест лишения свободы. В связи с актуальностью темы безработицы на территории Российской Федерации в целом ряде случаев подобная информационная доступность сможет оказать помощь заключенным в создании своего бизнеса после освобождения из мест реального лишения свободы, что является необходимым условием для перевоспитания и исправления любого осужденного. Учитывая огромный ресурсный потенциал Интернета, сложно предположить негативное восприятие подобной новации в сфере библиотечной деятельности в местах лишения свободы. Социальное значение такого нововведения может быть оценено как актуальное и исключительно положительное.

При условии внесения необходимых изменений в действующее сегодня законодательство, библиотеки в местах лишения свободы смогут быть обеспечены компьютерной техникой и средствами телекоммуникаций. Соответствующие информационно-образовательные услуги смогли бы стать доступными для весьма значительного количества граждан, составляющих категорию так называемого «специального контингента», т. е. лиц, содержащихся в условиях изоляции от общества.

Лица, отбывающие наказание в российских местах лишения свободы, должны иметь доступ в полном объеме к ресурсам информации и музыкальным библиотекам. Музыка при любых обстоятельствах способна оказать исключительно благотворное влияние на процесс воспитания лиц, допустивших в силу определенных причин нарушение уголовного закона.

Длительность времени пребывания людей в местах лишения свободы может способствовать глубокому изучению целого комплекса произведений музыкальной культуры, содержащегося в библиотечных фондах. Такая деятельность изолированных от общества граждан отвлечет их от других, менее приличных занятий.

С внедрением современных технологий стало возможным использование информации, находящейся не только на территории России, но и на территории других государств. Используя ресурсы Интернета, пользователи имеют доступ к различным ресурсам музыкальных библиотек государств мира. Подобные музыкальные коллекции могут находиться как в государственных библиотеках, так и в частных собраниях.

Необходимо популяризировать среди рассматриваемой категории граждан такую музы- кальную информацию. Целесообразно проведение реформирования законодательства Российской Федерации с целью разрешения заключенным использования Интернета для поиска музыкальных коллекций.

Режимные ограничения не позволяют в современных российских условиях в полной мере реализовать рекомендации Международной федерации библиотечных ассоциаций и учреждений, в которых анализируется вопрос о целесообразности использования в библиотеках для лиц, лишенных свободы, возможностей Интернета. Предполагается, что в дальнейшей перспективе данная ситуация изменится, и технический прогресс будет способствовать самообразованию заключенных под стражу лиц.

С вступлением России в Совет Европы весьма значительное влияние на российское законодательство оказывает практика Европейского суда по правам человека. Принятые Европейским судом по правам человека 29 января 2009 г. решения против России приводят некоторых отечественных ученых к мысли о необходимости внесения принципиальных изменений и дополнений в ряд отраслей российского законодательства. В решениях суда констатировались многочисленные нарушения статьи 3 Европейской Конвенции по правам человека, в частности, запрета на пытки и бесчеловечное обращение (Окончательное решение по делу № 1750/03 от 29.01.09 г. по делу В. Андреевский против России; Окончательное решение по делу № 22107/03 от 29.01.09 г. по жалобе Д. Антропов против России; Окончательное решение по делу № 6954/02 от 29.01.09 г. по жалобал А. и А. Малтабаровы против России). Особое внимание было уделено недостаточным размерам площади жилых помещений и иным нарушениям правил санитарии и гигиены в местах лишения свободы в Российской Федерации. До настоящего времени сколько-нибудь значительных изменений ни в российское законодательство, ни в отечественную правоприменительную практику, к сожалению, внесено не было. В результате этого около 1 млн заключенных в России продолжают испытывать указанные трудности, что не соответствует положениям о законности и демократии. Данная точка зрения наглядно и однозначно нашла свое отражение в судебных актах, неоднократно вынесенных Европейским судом по правам человека по делам против России.

Содержащие подобную информацию полиграфические издания в самых разных формах (книги, брошюры и т. п.) необходимо разместить в библиотеках, доступных для лиц, отбывающих наказание в виде лишения свободы по приговору суда на территории России. Такие издания, кроме того, могут быть в значительной степени востребованы (приобретены) и родственниками осужденных. 
Особую актуальность сведения, содержащиеся в указанных выше решениях Европейского суда по правам человека, представляют для несовершеннолетних, отбывающих наказание в виде лишения свободы по приговору суда. В силу своей значительно меньшей по сравнению со взрослыми правонарушителями социальной защищенности несовершеннолетние в большей степени испытывают потребность в столь актуальной для них информации.

Воспользовавшись данной информацией, заинтересованные лица смогут самостоятельно, либо с помощью квалифицированных помощников обратиться за констатацией нарушения своих прав и необходимостью вынесения решений в свою пользу. Полученные при этом материальные средства смогут облегчить процесс их адаптации. Подобные меры, несомненно, увеличат роль книги в широких слоях российского общества.

Отдельного одобрения может заслуживать и практика служителей церкви, которые, помимо проведения служб и общения с заключенными, создают библиотеки в тюрьмах и колониях для их духовного воспитания. Основная масса литературы в библиотеках касается культурного мирового наследия [3], достаточное место отводится также религиозной литературе [2].

Совершенствуя сложившуюся сегодня ситуацию с обеспечением лиц, содержащихся в условиях реального лишения свободы, возможностью доступа к библиотечным фондам, особое внимание надлежит обратить на увеличение в данном аспекте потенциала межбиблиотечного и международного абонемента. Кроме того, принимая во внимание наличие в российских местах лишения свободы значительного числа лиц, страдающих туберкулезом и иными социально-опасными заболеваниями, в целях недопущения дальнейшего ухудшения эпидемического состояния целесообразно расширить возможности предоставления таким лицам доступа к электронным копиям соответствующих книжных фондов.

\section{Список источников}

1. Бахурина Л.С. Отношение осужденных, отбывающих наказание в Икшанской воспитательной колонии, к книге, чтению и библиотеке : отчет об исследовании / Л.С. Бахурина, А.В. Янков ; РГЮБ. - М., 2000. - С. 15.

2. Ганьжин А.И. Роль церкви в духовно-нравственном воспитании в тюрьмах // Изв. Рос. гос. пед. ун-та им. А.И. Герцена. — 2010. — № 121. — СПб. : РГПУ им. А.И. Герцена. - С. $79-84$.

3. Каган M.С. Философия культуры : сб. трудов. - СПб. : Питер, 1996. - С. 29.

4. Лелан В. Руководство по библиотечному обслуживанию заключенных / В. Леман, Д. Локк / П Профессиональные отчеты ИФЛА. — № 93. - Гаага, Штабквартира IFLA, 2006. - 24 с. (Пересмотренный вариант профессионального отчета IFLA, № 46).

5. Таращенко A.A. Специфика работы с читателями исправительных учреждений // Науч. и техн. б-ки. - 1997. - № 5. - С. 46.

6. Шапошников А.Е. Тюремные библиотеки : история и современность // Книга. Исслед. и материалы. Сб. 81. - М. : Наука, 2003. - С. 74-86.

7. Шошин C.B. Библиотеки-хранители и распространители исторических и культурных знаний, связанных с развитием правовой системы России // Румянцевские чтения - 2010. Ч. 2 : материалы междунар. науч. конф. (2022 апр. 2010 г.) / Рос. гос. б-ка ; [сост. М.Е. Ермакова]. - М. : Пашков дом, 2010. - C. $254-258$.

8. Он же. Некоторые направления дальнейшей реализации приоритетных национальных проектов // Научное, экспертно-аналитическое и информационное обеспечение стратегического управления, разработки и реализации приоритетных национальных проектов и программ : сб. науч. тр. / ИНИОН РАН. - М., 2007. - С. 337. 